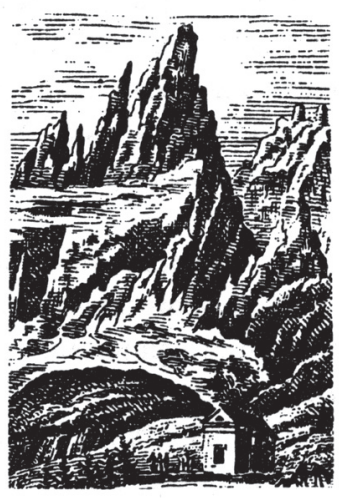

Kai Reinhart

Westfalski Uniwersytet Wilhelma w Münsterze kai.reinhart@uni-muenster.de

DOI: 10.19195/2084-4107.12.22

\title{
Incognito przez kraj przyjaciół. Nielegalni wspinacze z NRD w Związku Radzieckim*
} podróże

Słowa-klucze: NRD, Związek Radziecki, turystyka piesza, wspinaczka górska, przygoda,

Keywords: GDR, Soviet Union, hiking, mountaineering, adventure, travelling

\section{Incognito through a country of friends: Illegal climbers from the GDR in the Soviet Union}

\section{Summary}

Although the GDR did not have its own high mountains, it did have an informal community of climbers, of about 1,000 enthusiasts, who despite numerous obstacles managed to go on expeditions to high mountains of the Eastern Bloc. They could not count on any support of the state, because mountaineering is not a kind of sport in which international success can be achieved all the time and because the GDR, unlike e.g. the Soviet Union, could not expect any military benefits from it.

* Przekład na podstawie artykułu K. Reinhart, Unerkannt durch Freundesland - Illegale DDR-Bergsteiger in der Sowjetunion, http://www.bpb.de/geschichte/zeitgeschichte/deutschlandarchiv/53586/unerkannt-durch-freundesland?p=all (dostęp: 1.06.2018). 
The climbers found it especially hard to obtain permission to travel, to go to the mountains on their own, to acquire appropriate equipment and train in preparation for the difficulties awaiting them in high mountains. Only thanks to their extraordinary enthusiasm, organisational creativity and technical skills were they able to overcome obstacles like obtaining invitations from the Soviet Union, casual jobs and making their own equipment in order to be able to reach high mountains.

From the late 1970s the climbing community began to experience a revival thanks to a new "hippie generation". Young people reached the USSR thanks to the so-called "transit visas", which is why they were described as "transit travellers". Often they would then travel for weeks or even months "unrecognised through their beloved country". During these "incognito travels" they had to avoid police patrols and when they were stopped, they had to have good excuses. Despite their illegality, the transit travellers were able to travel across the entire USSR. Their extraordinarily modest way of travelling, often hitch-hiking or walking, meant that they had closer contact with people living in the Soviet Union than was provided for in the German-Soviet friendship, used for propaganda purposes, and could formulate their own opinion on the reality of the "Big Brother".

Through their experiences the climbers managed to distance themselves from the official socialist discourse in the GDR. With their views crossing state borders the climbers could be treated as the vanguard of mass escapes through Eastern European third countries, like e.g. Hungary, which began the collapse of the GDR in 1989.

Najwyższym wzniesieniem w NRD był Fichtelberg w Erzgebirge/Rudawach (obecnie ta część pasma znajduje się w obrębie granic Niemiec), mierzący 1214 metrów, w związku z czym Niemcy Wschodnie niekoniecznie były eldorado dla wspinaczy. Mimo tego wspinaczka górska w Saksonii miała długą tradycję — zainspirowana skalnymi basztami Elbsandsteingebirge/Gór Połabskich już w drugiej połowie XIX wieku zaczęła się tu rozwijać lokalna kultura wspinaczkowa i zwyczaj chodzenia po górach; w latach trzydziestych XX wieku w Dreźnie istniało około 300 stowarzyszeń turystycznych z około 30 tysiącami członków. Znani saksońscy wspinacze, jak Oscar Schuster czy Fritz Wiessner, mieli wpływ na sposób chodzenia po górach na wielu górskich obszarach na świecie. Po II wojnie światowej warunki dla przedsięwzięć turystycznych — ze względów ideologicznych, politycznych, finansowych i materialnych — pogorszyły się dramatycznie.

\section{Konflikt ideologiczno-polityczny}

Według Kurta B. Richtera, socjalistycznego autora piszącego o górach, do wspinaczki górskiej już w XIX wieku wkradł się „pusty idealizm i mistycyzm”: „Od owych czasów przetrwał obraz wspinacza ukazujący w romantycznej otoczce amatora przygód, dla którego góry są wszystkim i który ignoruje realny świat istniejący za górami"'. Mieszczaństwo celowo propagowało pogląd, że w górach nie ma walki klasowej, a polityka nie ma tam czego szukać. Postawa ta była zaciekle zwalczana w sporcie NRD — „Hasłu »Tylko sport« przeciwstawiano hasło »Każdy sportowiec aktywistą«"2. Cel aktywności sportowców uwidocznio-

\footnotetext{
${ }^{1}$ K.B. Richter, Der Sächsische Bergsteiger, Berlin 1962, s. 10.

2 Geschichte der Körperkultur in Deutschland 1945-1961, red. W. Eichel et al., Berlin 1967, s. 40.
} 
no w motcie odznaki sportowej NRD, które odpowiednio do sowieckiego wzoru brzmiało „Gotów do pracy i obrony ojczyzny”. Odznaka sportowa uważana była w związku z tym za ,podstawowy normatyw” sprawności socjalistycznych osobowości. By go wypełnić i przyczynić się do kształtowania socjalizmu, Walter Ulbricht żądał od 1968 roku, aby ,każdy, w każdym miejscu, co tydzień wielokrotnie uprawiał sport"3.

Również turysta z NRD dążył zatem do tego, „by poznać i pokochać swoją ojczyznę [...] i utrzymywać się w interesie postępu w zdrowiu, sile i gotowości do obrony i rozwiązywania zadań społecznych", jak pisał przewodniczący sekcji turystyki NRD Heinz Schlosser w 1955 roku4 . W rzeczywistości motywacja większości wspinaczy była całkiem inna. Na skutek ich doświadczeń z Trzecią Rzeszą i z nowymi komunistycznymi władcami ich nieufność w stosunku do państwa i polityki po II wojnie światowej jeszcze wzrosła: „Nie, tego błędu, by uwierzyć w tego rodzaju brutalną ideologię doskonalenia się, nie popełnimy ponownie tak szybko" - mówił Dietrich Hasse 5 . W przeciwieństwie do państwa, do którego podchodzono nieufnie, natura i przyjaźń jawiły się jako wielkie i prawdziwe. Karlheinz Gonda, jeden z wiodących wspinaczy tych lat, napisał nawet wiersz o ,przyjaciołach z gór”:

Gdy dwóch razem dąży

w swobodnej górskiej naturze,

idą przez całe życie

połączeni śladem wolności.

Przyjaciółmi gór jest wtedy

dwóch połączonych jak jeden,

i atakują światy.

Rozdzielić ich nikt nie zdoła ${ }^{6}$.

Wspinaczka górska zamiast być działaniem, dzięki któremu można by „,przygotowywać się do pracy i obrony ojczyzny", mogła prowadzić do tego, że praca zawodowa stawała się sprawą drugorzędną: „My byliśmy właściwie głównie tymi, którzy wtedy pracowali w organizacjach kościelnych, ponieważ tam pozostawiano nas po prostu w spokoju. [...] mieliśmy spokój, a resztę przeżywało się w Szwajcarii Saksońskiej" - mówił świadek tamtych czasów ${ }^{7}$. Ostatecznie wspinacze nie

3 Körperkultur und Sport in der DDR. Dokumentation eines geschlossenen Systems, red. H. Bernett, Schorndorf 1994, s. 36.

${ }^{4}$ H. Schlosser, Die Touristik - ein Mittel zur patriotischen Erziehung unserer Jugend und der Werktätigen, „Theorie und Praxis der Körperkultur” 4, 1955, s. 481-488.

5 D. Hasse, Erinnerungen an die Nachkriegszeit im Elbsandsteingebirge, [w:] F. Richter, Klettern im Elbsandsteingebirge, München 1993, s. 36-41.

${ }^{6}$ H. Richter, In memoriam Karlheinz Gonda, „Aus der Sächsischen Bergsteigergeschichte” 9, 2003, s. 19-21.

7 Falk Schelzel (ur. 1963) - wychował się w Saksonii, czołowy wspinacz w latach 1980-1983, w 1984 roku wyjechał do Bawarii, prowadzi własny zakład dekarski. Autor niniejszego tekstu przeprowadził z nim rozmowę 22 listopada 2004 roku. 
dawali się reedukować, o czym świadczą między innymi liczne krytyczne wpisy w księgach wejść ze Szwajcarii Saksońskiej:

„Może się ludzkość w szponach tyranów wić, my będziemy w górach prawem do wolności żyć!"

„Jest wiele granic dla człowieka / wymyślonych / i / strzeżonych! [trzy nieczytelne podpisy]"9.

Szczególnie w latach osiemdziesiątych XX wieku wielu młodych wspinaczy wykorzystywało wspinaczkę w Szwajcarii Saksońskiej, by wewnętrznie wziąć rozbrat z państwem robotników i chłopów. Jak wspomina jeden ze świadków owych czasów:

Po prostu siedziałeś rzeczywiście z grupą ludzi wieczorem przy ognisku, gdzieś pod ogromnym nawisem skalnym i byłeś po prostu daleko od wszystkiego. A więc to bycie innym, niemieszczenie się w tej normie, było dla wielu całkiem poważną myśląi ${ }^{10}$.

\section{Przepisy podróżne dla obywateli NRD}

W latach czterdziestych i pięćdziesiątych XX wieku wielu wspinaczy mogło jeszcze spełniać swoje marzenie o górach poprzez nielegalne wyjazdy w Alpy ${ }^{11}$, lecz wraz z budową muru berlińskiego Alpy przestały być osiągalne. Tak rymował o tym wspinacz w księdze wejść ze Szwajcarii Saksońskiej:

Och, Alpejski kraju, jaki jesteś piękny, możemy cię niestety zobaczyć tylko jako emeryci.

$[\ldots]$

Świat jest piękny, tak wielki i rozległy,

tylko ten, kto go zna, wielce się zachwyci.

Ta radość tu jest rzadka i ktoś powie: utkwiliśmy na zawsze w Dedeerowie ${ }^{12}$.

${ }^{8}$ Księga wejść Lößnitzturm, 1966, Archiwum ksiąg wejść Saksońskiego Związku Wspinaczkowego (SBB).

${ }^{9}$ GB Weberschluchtstein, 1.01.1983, Archiwum ksiąg wejść Saksońskiego Związku Wspinaczkowego (SBB).

10 Uwe Schönfisch „Schöni” (ur. 1967) — wychował się w Berlinie, czołowy wspinacz, odpowiedzialny za rozpracowanie obszaru Boulder Quackenwald pod Ludwigsfelde/Berlin, w 1989 roku uciekał z NRD przez Węgry; dekarz, kupiec, kierownik sklepu sportowego. Autor niniejszego tekstu przeprowadził z nim rozmowę 30 lipca 2004 roku.

${ }^{11}$ R. Wankerl, Münchner Sachsen, [w:] Felsenheimat Elbsandsteingebirge. Sächsisch-Böhmische Schweiz: Erlebnis eine Landschaft und ihrer künstlerischen Darstellung. Ein Jahrhundert sächsisches Bergsteigen, red. D. Hasse, H.L. Stutte, Wolfratshausen 1979, s. 238-254.

12 Księga wejść Heringshorn, 1987, Gipfelbucharchiv des Sächsischen Bergsteigerbundes (SBB) [archiwum książek szczytowych Saksońskiego Związku Wspinaczy (SBB)]. 
Aby nie wzbudzać niepotrzebnych tęsknot, Alpy stały się w mediach tabu. Jak wspominał dziennikarz sportowy Horst Mempel: „O Alpach nie rozmawiano. Ich właściwie nie było" "13. W ten sposób alpiniści siłą rzeczy kierowali swoje spojrzenia na Wschód - w Związku Radzieckim były wielkie góry, których szczyty miały niekiedy powyżej 7 tysięcy metrów. Nie tylko jednak w odniesieniu do „niesocjalistycznej zagranicy” (kraje kapitalistyczne), lecz także w obrębie Bloku Wschodniego możliwości podróżowania były mocno ograniczone. Teoretycznie istniała możliwość przyłączania się do zorganizowanych wycieczek, które oferowało Reisebüro der DDR i organizator podróży z ramienia FDJ — Jugendtourist, jednak ta oferta była tak skromna, że tylko bardzo niewielu, wybranych wspinaczy mogło z niej skorzystać.

\section{Podróżowanie na podstawie „wizy tranzytowej”}

Kto nie chciał czekać na taką okazję, musiał wziąć organizację podróży we własne ręce i pokonać liczne biurokratyczne przeszkody. Od 1964 roku dla obywateli NRD istniała możliwość wyjazdu bez wizy do krajów Bloku Wschodniego, do czego konieczny był ,plan podróży w ramach bezdewizowego ruchu wycieczkowego", „wniosek na wyjazd z Niemieckiej Republiki Demokratycznej” i dowód osobisty. Taki plan podróży wystawiany był jednak nie przez ZSRR, lecz przez powiatowe komendy policji NRD, która zasadniczo nie miała nic przeciw podróży do „Wielkiego Brata”, jeżeli tylko zakwalifikowali wnioskodawcę jako lojalnego obywatela NRD ${ }^{14}$.

Już w przepisach podróżnych z 1964 roku była również przewidziana możliwość przejazdu przez ZSRR, by dostać się do kraju trzeciego. Ponieważ jednak mass media nie informowały o nowych przepisach, początkowo były one większości całkowicie nieznane. $Z$ biegiem czasu ta furtka w socjalistycznym ruchu transgranicznym spopularyzowała się jednak w sferach wspinaczy i autostopowiczów. Jeśli komuś udało się przejechać przez granicę, zbaczał więc z wyznaczo-

13 Horst Mempel (ur. 1938) - wychował się w Sachsen-Anhalt, w 1965 roku został mistrzem NRD w dziesięcioboju, przez pewien czas działał jako TW Stasi; reporter sportowy i turystyczny w telewizji NRD i w MDR. Autor niniejszego tekstu przeprowadził z nim rozmowę 4 października 2004 roku.

14 T. Austermühle, Unerkannt durch Freundesland. Abenteuertourismus jenseits staatlicher Sanktionen, [w:] Alltagssport in der DDR, red. J. Hinsching, Aachen 1998, s. 272-281; R. Bauch, E. Nönnig, A. Pamir, Von der DDR in die Bergwelt Tadshikistans, [w:] Alpenvereinsjahrbuch Berg, red. Deutscher Alpenverein München (DAV), Österreichischer Alpenverein (ÖAV), Alpenverein Südtirol (AVS), München-Innsbruck-Bozen 1998, s. 251-258; R. Leiserowitz, Unerkannt durch Freundesland. Subversiv reisen mit Transitvisa, [w:] Bye bye Lübben City: Bluesfreaks, Tramps und Hippies in der DDR, red. M. Rauhut, T. Kochan, Berlin 2004, s. 134; Ch. Halbrock, Unterwegs im Land des , Bruderorgans”. Transitabweichler und Reisegruppenflüchtige im Spiegel der MfS-Akten, [w:] Unerkannt durch Freundesland. Illegal Reisen durch das Sowjetreich, red. C. Klauß, F. Böttcher, Berlin 2010, s. 360-389. 
nej trasy tranzytowej i pozostawał, zamiast dozwolonych jednego lub dwóch dni, przez wiele tygodni lub nawet miesięcy nielegalnie w danym kraju.

Opowiadania i pokazy przeźroczy pierwszych podróżników przyciągały następnych młodych ludzi, tak że w latach siedemdziesiątych i osiemdziesiątych XX wieku pod żartobliwymi pojęciami „nierozpoznany przez kraj ukochany” lub ,podróży tranzytowej” powstał ,gotowy na ryzyko ruch młodzieżowy”, który łączył w sobie „przygodę, ryzyko i wspinaczkę”"15. Ci „hippisi”, jak określał ich zachodnioniemiecki globtroter Uli Ulziffer ${ }^{16}$, byli głównie studentami, czasem aktywistami ruchu zajmowania pustostanów, niekiedy artystami, a często osobami aktywnymi w ruchu kościelnym i/lub ekologicznym. Ich poszukiwanie przygód prowadziło do najbardziej zdumiewających przedsięwzięćc ${ }^{17}$ - zaczęło się prawdziwe współzawodnictwo, kto pokona najwięcej kilometrów i dotrze do najbardziej egzotycznych miejsc.

O konsekwencjach przedłużonego pobytu bez uzyskania koniecznej zgody dla przedstawicieli tego ruchu początkowo nie było nic wiadomo. Doświadczenia pokazywały natomiast, że kary ze strony sowieckiej nie wykraczały poza ostrzeżenie, karę grzywny w wysokości 10-100 rubli lub zakaz wjazdu w następnych latach ${ }^{18}$. To ostatnie mogło boleśnie ugodzić tranzytowców, lecz szybko okazało się, że rosyjska administracja nie zamierzała lub też nie była w stanie nadzorować tych zakazów. W NRD w grę wchodziły oczywiście ostrzejsze konsekwencje, jak degradacja zawodowa, wyrzucenie ze studiów lub utrata dowodu osobistego, na co jednak się godzono ${ }^{19}$. Ostatecznie podróże tranzytowe rzadko kończyły się tak ciężkimi karami, ponieważ owi amatorzy kraju przyjaciół, nawet jeżeli późno, to i tak wracali do NRD, w związku z czym nie byli dla Ministerstwa Bezpieczeństwa Państwowego (Stasi) głównym problemem (ku niezadowoleniu organów sowieckich) ${ }^{20}$.

15 Karsten König (ur. 1960) - wychował się w Berlinie Wschodnim, odbył liczne podróże do Europy Wschodniej i ZSRR, organizował spotkania amamtorów incognito, w 1989 próbował uciec z NRD wraz z Reinhardem Tauchnitzem, jedyny enerdodwiec na ośmiotysieczniku (Shisha Pangma); squatter, doktor fizyki, habilitował się w dziedzinie biologii komórki, założyciel i prezes JenLab GmbH in Jena, profesor uniwersytetu w Saarbrücken (Katedra Mikrosensoryki), kierownik działu w Fraunhofer Institut für Biomedizinische Technik (IBMT) w St. Ingbert. Autor niniejszego tekstu przeprowadził z nim rozmowę 9 grudnia 2004 roku.

16 Uli Ulziffer (ur. 1942) - wychował się w Schleswig-Holstein, globtroter, odbył liczne podróże szczególnie po Bloku Wschodnim, nauczyciel przedmiotów zawodowych. Autor niniejszego tekstu przeprowadził z nim rozmowę 17 kwietnia 2005 roku.

17 C. Klauß, Unerkannt durch Freundesland - Verbotene Reisen in das Sowjetreich, BRDRBB, 11.12.2006 (ESD); Transit. Illegal durch die Weiten der Sowjetunion, red. J. Kuhbandner, J. Oelker, Radebeul 2010; Unerkannt durch Freundesland...

18 Ch. Halbrock, op. cit., s. 360-389.

19 T. Austermühle, op. cit., s. 272-281; R. Conrad, Wegen eines gelochten Fahrscheins unter Spionageverdacht, [w:] Unerkannt durch Freundesland..., s. 211-220.

20 Ch. Halbrock, op. cit., s. 364, 387. 


\section{Nierozpoznany przez kraj ukochany}

Jeżeli tranzytowcy zbaczali w Związku Radzieckim z wyznaczonej trasy, musieli poruszać się przez kraj przyjaciół incognito. Do tego potrzebne było możliwie nierzucające się w oczy zachowanie, co dla Europejczyków, do tego wyposażonych w strój wspinaczkowy, oczywiście było sprawą dość trudną, szczególnie w azjatyckich regionach tego wielkiego kraju. Już samo robienie zdjęć z dala od zwykłych atrakcji turystycznych wzbudzało nieufność miejscowych lub milicji. „Kiedyś przy dworcu myłem sobie przy studni zęby. Zaraz przyjechała milicja i wzięła mnie" - wspomina Reinhard Tauchnitz.

Aresztowanie obcokrajowca, którego trudno było przyporządkować do właściwego rejonu, bez właściwych dokumentów mogło być jednak dla milicji uciążliwe. I tak dwaj amatorzy przygód zdziwili się, że ich wiza tranzy towa do Rumunii została zaakceptowana w Kazachstanie: „Myśl, że milicjanci i kapitan być może byli zadowoleni, że mogli nas pierwszym lepszym pociągiem usunąć z zakresu swojej kompetencji, zaświtała nam dopiero później”21. Jeżeli przypadkowo milicjant był jeszcze wcześniej żołnierzem stacjonującym w NRD, mogło się zdarzyć, że cieszył się, iż może przy kilku kieliszkach wódki wznieść toast z nieoczekiwanymi gośćmi za „najlepszy okres swojego życia” i móc oddać się wspomnieniom ${ }^{22}$. Tu ujawniały się humor, elastyczność i wielkoduszność, której często brakowało urzędnikom enerdowskim ${ }^{23}$.

Ważne dla łagodnego przebiegu kontroli były pozornie wiarygodne wykręty. Dwóch kolegów połączonych liną wspinaczkową mogło szybko stać się „socjalistyczną brygadą studencką", która pomaga w odbudowie Taszkientu, co udowadniano (alpinistycznymi) „,budowlanymi hełmami ochronnymi”; lub że namiot został splądrowany przez niedźwiedzie, przez co niestety stracili dokumenty ${ }^{24}$. Wraz ze wzrostem doświadczenia amatorzy podróży incognito stawali się coraz sprytniejsi i łatwiej im szło wykorzystywanie słabości sowieckiej biurokracji. W dalekiej Azji Środkowej kontrolerom pokazywano nieistotne, ale wyglądające na ważne papiery, jak na przykład enerdowska legitymacja ubezpieczenia społecznego, w której były wbite stemple krwiodawstwa, wizyt u lekarzy czy pobytu w szpitalu:

Miała ona z przodu herb NRD i wyglądała bardziej na paszport. I tę legitymację z reguły przedkładaliśmy — częściowo odciskaliśmy tam

${ }^{21}$ U. Tayert, J. Strümpel, Asien begann in Makat, [w:] Unerkannt durch Freundesland..., s. 235.

22 Rozmowa z K. Königem z 9 grudnia 2004 roku.

${ }^{23}$ H. Beil, Mein Siebentausender war die Krim, [w:] Unerkannt durch Freundesland..., s. $185-199$.

24 T. Austermühle, op. cit., s. 274. 
również własne stemple - i mówiliśmy: „Tutaj są wszystkie pozwolenia”. Oni i tak nie mogli tego wszystkiego odczytać, a robiło to na nich zawsze duże wrażenie ${ }^{25}$.

Opatrzone licznymi stemplami, podrobione pisma tranzytowców nadawały im w Związku Radzieckim prawie że oficjalny status i tym samym torowały drogę.

Były jeszcze bezczelniejsze triki, które można by wprost nazwać „socjalistycznymi kawałami Dyla Sowizdrzała". Niektórzy amatorzy podróży incognito sami delegowali się więc w imieniu zakładowego klubu sportowego, by wspiąć się na określony szczyt i podnieść tam flagę przyjaźni. Sowieccy urzędnicy nie potrafili przyporządkować tych działań do obowiązujących przepisów. Już samo to, że ktoś na dalekich rubieżach kraju mógł przebywać nielegalnie, było dla nich wprost niewyobrażalne, a indywidualne podróże dla wielu milicjantów wyrosłych w socjaliźmie były wręcz nie do pomyślenia: „To, że mogą być podróżni, którzy nie podróżują z grupą, tego nie potrafili pojąć, a my mówiliśmy wtedy po prostu »OK, jutro rano jedziemy znowu do naszej grupy do hotelu«, i tym samym sprawa była załatwiona" 26 .

Nielegalność amatorów podróży incognito miała również swoje konsekwencje dla komfortu podróżowania. Noclegi w hotelach lub na oficjalnych polach namiotowych bez ważnych dokumentów były prawie niemożliwe - tak samo zakup biletów na samolot lub pociąg w Intouriście, gdzie obcokrajowców traktowano w sposób uprzywilejowany. Poza tym bilety Intouristu były dla „hippisów” najczęściej za drogie. Amatorzy incognito musieli w związku z tym podróżować w warunkach, do których przyzwyczajeni byli tubylcy, co oznaczało wielogodzinne lub wielodniowe okresy oczekiwania i walkę o miejsce przy okienku. Talent negocjacyjny i umiejętność improwizacji były bezwarunkowymi podstawami takiej podróży.

W pobliżu gór alpiniści mogli często posuwać się dalej tylko na piechotę, co mogło oznaczać wielotygodniowe marsze po bezdrożach w otoczeniu dzikiej natury. By nie zostać odkrytymi w górach, amatorzy incognito byli często zmuszeni nawet w górach opuszczać zwykłe szlaki i liczyć się z potężnym ryzykiem. Dłuższe okresy aklimatyzacji na dużych wysokościach były w tych warunkach często niemożliwe. Na skutek uciążliwości takiej ekspedycji wspinacze po powrocie byli zazwyczaj tak wyczerpani, że wielotygodniowe zwolnienia lekarskie, które miały usprawiedliwiać u pracodawców długie nieobecności, nie wzbudzały nieufności.

$\mathrm{Z}$ powodu sposobu podróżowania amatorzy incognito wchodzili w dużo bliższy kontakt z tubylczą ludnością, niż umożliwiały to puste rytuały Towarzystwa Przyjaźni Niemiecko-Sowieckiej27. Szczególnie w prostych wagonach trzeciej klasy i jadąc autostopem, dawało się szybko nawiązać kontakt z miejscowymi i zdo-

25 Rozmowa z K. Königem z 9 grudnia 2004 roku.

${ }^{26}$ Gerald Krug (ur. 1971) — wychował się w Brandenburgu, odbył liczne podróże wspinaczkowe w góry na Wschodzie; dyplomowany geograf, autor i wydawca literatury wspinaczkowej i podróżniczej. Autor niniejszego tekstu przeprowadził z nim rozmowę 15 lipca 2004 roku.

27 T. Austermühle, op. cit., s. 272-281. 
być ich zaufanie. „We wszystkich tych sportowych przedsięwzięciach [...] właściwym objawieniem były spotkania z ludźmi" 28 . Na wsiach panowały w dodatku tradycyjne zasady gościnności i często tranzytowcy byli zapraszani na wesołe zabawy. Nawiązanie bliskich kontaktów z tubylcami nie było czymś, co musieli siłą rzeczy akceptować, lecz dość często wręcz jednym z celów podróży. Tranzytowcy życzyli sobie, by „obok oficjalnych poglądów móc sobie wyrobić własne zdanie i poznać inne kultury" 29 . Nie tylko miejscowych, ale też podobnie myślące osoby z Niemiec Zachodnich, a ponadto z całego świata zachodniego, mogli spotkać na swojej drodze tranzytowcy z NRD (czemu Stasi przypatrywało się ze szczególnym zatroskaniem) $)^{30}$. W ten sposób na przykład zachodnioniemiecki globtroter Uli Ulziffer poznał środowisko tranzytowców i został zaproszony na spotkanie amatorów podróży incognito do NRD, a także pomagał wspinaczom przy zdobywaniu dewiz i wyposażenia.

\section{Przeszkody finansowe i materialne}

Oprócz ograniczonej swobody podróżowania również kwestie finansowe i materialne stanowiły olbrzymie przeszkody dla wybierających się w dalekie góry. By zarobić pieniądze, które były potrzebne do większości prywatnych ekspedycji, nieodzowna była własna inicjatywa. Georg Renner na swoje podróże zabierał około 15 kilogramów wyposażenia fotograficznego i wykonywał w ciągu roku kilka tysięcy zdjęć rosyjskiego świata gór. Następnie, dzięki znajomościom, mógł z niektórych motywów drukować nawet po 15 tysięcy plakatów.

Były to jedyne takie plakaty w NRD, dzięki czemu rozchodziły się w sklepach sportowych i sekcjach wspinaczkowych jak ciepłe bułeczki.

Niektórych elementów wyposażenia, które są niezbędne turystom w górach lodowcowych, nie dało się dostać oficjalną drogą, nawet za duże pieniądze. Pewne rzeczy można było rozdzielać poprzez zakładowe kluby sportowe lub też zakupić przez zakłady pracy. Inne materiały trzeba było zdobywać na czarnym rynku, który obsługiwany był przez pomysłowych wspinaczy z umiejętnościami rzemieślniczymi. Na przykład Erhard Klingner handlował własnoręcznie wykonanymi uprzężami do wspinaczki - zwykła uprząż Klingnera kosztowała około 25 marek, dzięki czemu mógł on sobie przy tym odrobinę dorobić31.

Mimo takiego operowania w szarej strefie niezbędne były pomysłowość i osobiste zdolności rzemieślnicze oraz dostęp wspinaczy z NRD do materiałów i narzędzi. Prawie wszystko — od bielizny do plecaka — było robione własnym sump-

28 I. Böhning, Vom Wohnkomplex 5 E in Hoywoy ans Schwarze Meer (1970-1976), [w:] Unerkannt durch Freundesland..., s. 93-102.

${ }^{29}$ Rozmowa z K. Königem z 9 grudnia 2004 roku.

30 Ch. Halbrock, op. cit., s. 360-389.

31 Erhard Klingner (ur. 1943) — wychował się w Saksonii, prywatnie produkował i sprzedawał wyposażenie wspinaczkowe na czarny rynek, odbył liczne ekspedycje; niezależny inżynier dyplomowany. Autor niniejszego tekstu przeprowadził z nim rozmowę 4 sierpnia 2004 roku. 
tem. Oczywiście takiego wyprodukowanego własnymi rękami wyposażenia nie można było porównywać z nowoczesnymi wytworami High-Tech, a pełne plecaki potrafiły ważyć powyżej 40 kilogramów. Wyposażenie z Zachodu było w związku z tym w całym Bloku Wschodnim bardzo poszukiwane. Reinhold Messner pisał, że w trakcie jednej z podróży do Związku Radzieckiego wspinacze wyrywali sobie $\mathrm{z}$ rąk jego buty z plastiku czy ubrania z gore-texu ${ }^{32}$. Ile wysiłku w sumie kosztowało zdobycie kompletnego wyposażenia, pokazuje sprawozdanie Wolfganga Manna:

Puchowy śpiwór typu mumia nabyłem w Dreźnie, jak również parę butów wspinaczkowych z ČSSR, nienadających się jednak do zakładania raków. [...]. Czekan z drewnianą rączką wypożyczyłem z mojej sekcji w BSG Lok, a parę raków z lat 20. od jakiegoś amatora gór. Namioty na biwaki otrzymaliśmy w magazynie. Skarpety i rękawice były robione ręcznie. Wielkie torby wysuszonych moreli nabyłem po znajomości od kierownika sklepu sieci „Konsum”33.

Inny problem stanowiło dotarcie do szczegółowych map w odpowiedniej skali. W krajach socjalistycznych nabycie map ze względów bezpieczeństwa było prawie niemożliwe, zwłaszcza dostanie map regionów granicznych wrażliwych politycznie i militarnie, w których leżało wiele interesujących masywów górskich. Radzieckie czasopismo dla wspinaczy „Turist” i książki o górach niekiedy zawierały mapy, które z nich wycinano lub odrysowywano. Również w „komisach” czy księgarniach można było czasami zdobyć antykwaryczne skarby, na których wspinacze, mimo upływu czasu, musieli polegać. Przykładowo Karsten König wspiął się na Pik Lenina, wykorzystując mapy, które opublikowało Niemiecko-Austriackie Towarzystwo Alpejskie po jego pierwszym zdobyciu w 1928 roku. Takie mapy były doprecyzowywane i aktualizowane na podstawie osobistych podróży i wymiany doświadczeń w środowisku. Kalka kreślarska należała w związku z tym do stałego wyposażenia wielu wspinaczy.

Georg Renner słynął w środowisku ze swoich samodzielnie rysowanych map, które były określane również jako „Mapy Rennera”. Jako inżynier biura projektów w Urzędzie Gospodarki Wodnej miał on dostęp do stołów kreślarskich i skal. Całymi nocami siedział zatem w zakładzie i zestawiał różne części map z sobą. W ten sposób narysował w sumie kilkaset map, których częściowe opracowanie zajmowało wiele tygodni. „Rosjanie biegali za nami, by dostać ode mnie mapy swojego kraju" - opowiadał nie bez dumy Renner. Pożądane dobro było przekazywane tylko z rąk do rąk, a jednak tą drogą rozprzestrzeniło się w całym środowisku i było wykorzystywane przez długie lata.

Mimo to rysowane własnoręcznie mapy i zdobywane informacje geograficzne wspinaczy zawierały luki, tak że ich ekspedycje często stawały się wieloletnim

32 R. Messner, Wettlauf zum Gipfel. Strategie und Taktik meiner Höchstleistungen, München-Berlin 1986, s. $73 \mathrm{n}$.

33 W. Mann, Die Alten vom Berge erzählen. Wie ich vor drei Jahrzehnten zum Elbrus kam, „Mitteilungen der DAV-Sektion Chemnitz” 2002, nr 23, s. 36-38. 
i wyczerpującym posuwaniem po omacku i rozpoznawaniem terenu ,metodą prób i błędów", co opisał chociażby Renner na przykładzie wyprawy do Pamiru na początku lat siedemdziesiątych XX wieku. Samolotem, koleją, autobusem i ciężarówką zbliżyli się wówczas do gór. Na koniec można było posuwać się dalej tylko na piechotę, przy czym w Pamirze, inaczej niż na przykład w Himalajach, nie było wydeptanych ścieżek trekingowych.

Po raz pierwszy więc stwierdziliśmy, że, aha, tam są te i te szczyty, no tak. Drugi raz pomyśleliśmy sobie, teraz spróbujemy drogi wspinaczkowej na Pik Korżeniewskiej, tak, no i wtedy długo szukaliśmy. Za trzecim razem weszliśmy na szczyt. Ale za każdym razem szliśmy wzdłuż rzeki Muksu, a Muksu jest najdzikszą rzeką Pamiru. Obłęd! ${ }^{34}$

Z kolei dla Mädera największą trudnością była - wskazywana we wspomnieniach — fascynacja podróżami w góry, która w dzisiejszych ekspedycjach częściowo znikła: „Wszędzie prowadzą one ludzi do góry i znowu na dół — ustawić się i do góry. To mnie już nie podnieca. Podnieca mnie wolna natura, to że robi się coś samodzielnie, że nikt nikomu niczego nie nakazuje" 35 .

\section{Stosunek wspinaczy i tranzytowców do NRD}

Ironiczną piosenkę Lot specjalny (Sonderflug) Haralda Wiemanna, która opisuje wymarzoną podróż w Himalaje, czyta się prawie jak podsumowanie opisanych problemów z działalnością górską w NRD:

Za 15 minut rozpoczyna się lot specjalny / 15 mężczyzn stoi wyczekująco przy samolocie, a na brzegu pasa startowego gdzieś / stoi prezydent DWBO / i szycha od sportu / kiwa niedbale łapą / on mówi w myślach: jesteśmy z Wami / wszystko dobrze przyjaciele i good bye [...]

aby na pewno nie zdarzył się wypadek / są liny tylko od Edelrieda / od Salewy są lekkie raki / bardzo lubiane w kręgach wspinaczy / od Stubaia są super haki / które jeszcze nigdy nie tkwiły w skale / materiał jest dobry i nowy / wszystkiego dobrego przyjaciele i good bye [...]

a potem w końcu wciągana jest nasza flaga / na szczycie powyżej 8000 metrów / i w tym eksponowanym miejscu / zostawiamy puszkę szczy tową

34 Georg Renner (ur. 1926) — dorastał w Karkonoszach, członek SS, przebywał w niewoli wojennej, odbył liczne ekspedycje w SU; zajmuje się półprofesjonalną produkcją map turystycznych, jest także autorem książek o tematyce górskiej; inżynier, specjalność budownictwo wodne. Autor niniejszego tekstu przeprowadził z nim rozmowę 7 kwietnia 2005 roku.

35 Christoph Mäder (ur. 1938) - wychował się w Erzgebirge, kierownik Bezirkstrainingsgemeinschaft (BTG) Alpinistik/Bergsteigen przy BSG Lok Südost Magdeburg, odbył liczne ekspedycje do Związku Radzieckiego i Mongolii, zorganizował nakręcenie sześciu filmów telewizyjnych o wspinaczce; członek SED; inżynier technologii żywności, kierownik zakładu konserw rybnych w NRD i Mongolii. Autor niniejszego tekstu przeprowadził z nim rozmowę 6 kwietnia 2005 roku. 
/ a w niej informacje dla tego, kto się tu znajdzie / że jesteśmy za socjalizmem / i ku chwale Republiki byliśmy tu / wszystkiego dobrego przyjaciele i niech żyje sport ${ }^{36}$.

Problemy ideologiczno-polityczne, kwestie swobody podróżowania, a także trudności w zdobyciu wyposażenia były dla alpinistów olbrzymimi przeszkodami. Po ośmiu strofach piosenka kończy się odpowiednio w gorzkim tonie: „to wszystko było tylko utopią / w życiu tego nigdy nie osiągniemy, / to jest zbyt piękne, by było prawdziwe, / wszystkiego dobrego przyjaciele, ponownie zaśnijcie!”.

Jednak, jak dowodzi sama piosenka, większość wspinaczy charakteryzowało zdrowe podejście do sprawy. Wielu starszych alpinistów przyswoiło sobie wprawdzie z biegiem lat pragmatyczną postawę w stosunku do socjalistycznego państwa $^{37}$ - jak wyjaśniał w wywiadzie Georg Renner: „My nienawidziliśmy NRD”, ponieważ blokowało im drogę do wymarzonych celów w Alpach czy Himalajach. Brakowało im również uznania oficjeli dla ich częściowo spektakularnych ekspedycji — ale przynajmniej nie trzeba ich było trzymać w tajemnicy. Renner wygłaszał oficjalne wykłady z przeźroczami o swoich podróżach, był też często wymieniany w prasie i publikował wiele książek o górach i podróżach.

Młodzi tranzytowcy lat siedemdziesiątych i osiemdziesiątych byli zawodowo i rodzinnie jeszcze bardziej niczym niezwiązani i nie bali się prowokować państwa. Dla Reinharda Tauchnitza w tym właśnie tkwił urok: „W zamyśle było wówczas od czasu do czasu odrobinę podrażnić oficjalne organy państwa”. Tauchnitz rozstał się mentalnie z NRD już pod koniec lat osiemdziesiątych. Wspólnie z Königiem podjęli decyzję o spektakularnej ucieczce: „Jeżeli to już zrobimy, to z przytupem. Pokażemy im tu naprawdę, jakich ludzi tracą. Wejdziemy na ośmotysięcznik, opiszą to wszystkie gazety, a oni się będą trochę złościć". Udało się - chociaż dopiero po upadku muru w 1990 roku — i zostało to zauważone w mediach ${ }^{38}$.

W obliczu prosowieckiej propagandy w NRD spotkanie ze Związkiem Radzieckim z dala od utartych szlaków turystycznych, gdzie obok wielu pięknych przeżyć uwidaczniała się jednocześnie bieda i zacofanie, konflikty etniczne i narodowe, przestępstwa (polityczne) i korupcja - doświadczenie, które nie pozostawało bez wpływu na światopogląd.

Enerdowcy spoglądali naturalnie trochę z góry na Związek Radziecki, ponieważ dostrzegali to, czego poza nimi w NRD nie wiedział nikt: że było dość prymitywnie [...], ale tego w domu nie mogli w ten sposób opowiadać, ponieważ tu mówiono o bohaterach, wyzwolicielach, którzy wystrzeliwują rakiety na księżyc ${ }^{39}$

\footnotetext{
36 Informacje pochodzą z wiadomości mailowej do autora artykułu z 13 kwietnia 2014 roku.

37 Rozmowa z Ch. Mäderem z 6 kwietnia 2005 roku.

38 M. Krüger, Einfach Spitze, diese Ossis!, „Super-Illu” 1990, s. 28-30.

39 Rozmowa z U. Ulzifferem z 17 kwietnia 2005 roku.
} 
— takie odniósł wrażenie Uli Ulziffer. Otwarcie takich przemyśleń nie można było w NRD opowiadać. I tak na przykład Stasi prowadziło dochodzenie w sprawie prywatnie zorganizowanego pokazu „Spektakl zdjęciowy w Rußdorf”, na którym podróżnicy incognito pokazywali przeźrocza ze swoich podróży ${ }^{40}$. Mimo to poszczególni wspinacze nie pozostawali ze swoimi doświadczeniami sami. W trakcie ich wspólnych podróży, a szczególnie w najróżniejszych miejscach spotkań środowiska wspinaczkowego, jak „Misthaus” Gustava Ginzela w czeskich górach Izerskich ${ }^{41}$, rozwinął się swoisty dyskurs, w którym pełzający upadek sowiecko-socjalistycznego władztwa już dawno stał się wiedzą ogólną.

W tradycji wspinaczkowej inspirowanej ich doświadczeniami z podróży wspinacze i tranzytowcy stworzyli i pielęgnowali w swoim środowisku własny romantyczny, tak zwany wspinaczkowy, styl życia ${ }^{42}$. „Stać na wysokim szczycie, tak blisko nieba, móc o wszystkim samemu decydować, podejmować ryzyko lub wracać, nie być na czyimś pasku — to świat, z którym byłem się w stanie identyfikować’"43. Wspinaczkowy styl życia mógł być całkowicie apolityczny, lecz w NRD miał mimo wszystko swoją polityczną stronę. Dla Jörna Beilkego wspinacze praktykowali pewien rodzaj odrzucenia, który ostatecznie ukierunkowany był jednak na zmiany polityczne: „To może nie był aktywny opór, [...] taki z ulotkami i czym tam jeszcze, ale to był po prostu opór, którym żyliśmy" 44 . Amatorzy podróży incognito „nie żądali wolności - mówił Michael Beleites - lecz ją praktykowali’"45. Oddziaływania takiej, wydawałoby się, apolitycznej postawy nie można nie doceniać — jak mówi filozof Wilhelm Schmid:

W tej postawie miała swoje oparcie wolność jednostki. Jest ona istotna nie tylko indywidualnie, lecz równie bardzo politycznie, ponieważ postawa jednostek wcześniej czy później musiała zostać uwzględniona w ostatecznym rozrachunku - Foucault wymienił w tym kontekście Polskę, lecz również koniec NRD może być tego przykładem ${ }^{46}$.

Politycznie konkretne odczuwalne odziaływanie wspinaczki górskiej polegało na wyjeździe lub ucieczce z NRD. Przed budową muru NRD opuścili licz-

${ }^{40}$ Ch. Halbrock, op. cit., s. 360-389.

41 K. König, Gustav Ginzel und sein Misthaus, „Impuls 68” 23, 1989, nr 3, s. 27-29.

42 D. Hasse, Bergsteigen als Spiel und die „Freiheit in den Bergen”, [w:] Felsenheimat Elbsandsteingebirge..., s. 14.

${ }^{43}$ Herbert Wünsche (ur. 1929) - wychował się w Saksonii; czołowy wspinacz okresu powojennego; w 1953 roku przeniósł się do Bawarii; odbył liczne ekspedycje; modelarz, pracownik kierownictwa w firmie BMW. Autor niniejszego tekstu przeprowadził z nim rozmowę 13 kwietnia 2005 roku.

44 Jörn Beilke (ur. 1968) — wychował się w Saksonii, od połowy lat osiemdziesiątych był w szczytowej formie; po studiach zajmował się budową maszyn; inżynier. Autor niniejszego tekstu przeprowadził z nim rozmowę 25 października 2004 roku.

45 M. Beleites, Litauische Wolken. Reisen ins sowjetische Baltikum 1985-1989, [w:] Unerkannt durch Freundesland..., s. 36.

46 W. Schmid, Auf der Suche nach einer neuen Lebenskunst. Die Frage nach dem Grund und die Neubegründung der Ethik bei Foucault, Frankfurt am Main 2000, s. 231. 
ni wspinacze, jak Herbert Wünsche, Harry Rost czy Dietrich Hasse. Po tym, gdy w latach sześćdziesiątych i siedemdziesiątych sytuacja się trochę ustabilizowała, w latach osiemdziesiątych ponownie pojawiła się prawdziwa fala ucieczek i wyjazdów.

Właśnie w środowisku wspinaczy było cholernie dużo takich, którzy wtedy również chcieli wyjechać, wtedy tworzyły się takie paczki. To szerzyło się wtedy jak zaraza [...] i myślano po raz pierwszy w ogóle o tym, i że to jest możliwe, i tak się to potem upowszechniło. To była więc taka komórka, która to spopularyzowała ${ }^{47}$.

Dla przepełnionych tęsknotą za wolnością i dalą wspinaczy zamurowany kraj stał się zbyt ciasny. Jako że byli doświadczeni w sprawach granicznych i biurokracji, było im o wiele łatwiej niż innym obywatelom NRD pokonywać mury socjalizmu. Alpinistów i tranzytowców można tym samym traktować jako pionierów masowych wyjazdów przez Węgry i inne kraje wschodnioeuropejskie, które zapoczątkowały w 1989 roku koniec NRD.

\section{Z języka niemieckiego przetożyła Eva Waszkowski}

47 Rozmowa z F. Schelzelem z 22 listopada 2004 roku. 